\title{
Pengaruh penggunaan media Webgis Inarisk terhadap kemampuan berpikir spasial siswa pada materi mitigasi dan adaptasi bencana
}

\author{
Agus Dwi Febrianto*, Purwanto*, Listyo Yudha Irawan* \\ * Jurusan Geografi Universitas Negeri Malang, Jl. Semarang No. 5 Malang, Jawa Timur, 65145, \\ Indonesia
}

\begin{tabular}{l}
\hline \hline ARTICLES INFO \\
\hline Profil Articles: \\
Sent: 7-2-2021 \\
Approved: 6-5-2021 \\
Published: 30-6-2021 \\
\hline
\end{tabular}

Key words:

Berpikir spasial; Webgis; Inarisk; mitigasi bencana; media

\begin{abstract}
Spatial thinking skills is needed in geography learning. Geography learning learns about the geosphere, which need to be studied from the perspective of spatial, environment, and regional complex. This is consistent with the concept of spatial thinking, which involves complex thinking processes from multiple perspectives to study various phenomena. This research aims to determine the effect and effectiveness of using webgis inarisk media towards spatial thinking skills. This research was conducted through a quantitative method with data analysis using TTest (Independent Sample T-Test) and the effectiveness test using (N-Gain Score Test). The results showed the Sig. (2-tailed) value in the analysis of the Independent Sample T-Test was 0.001 or more than 0.05. The average score of spatial thinking ability also showed that the experiment group (XI IPS 2) has a score of 70.3 which is higher than the control group (XI IPS 1) that is 64.2. Based on this, it is concluded that the webgis inarisk as a learning media has an effect on students' spatial thinking abilities. The results of the N-Gain Score test showed that webgis inarsik media used in experiment group (XI IPS 2) has better effectiveness in the achievement of spatial thinking skills, which is 43.7 percent, compared to map media used in control group (XI IPS 1) with an effectiveness of 32.09 percent.
\end{abstract}

Kemampuan berpikir spasial diperlukan dalam pembelajaran geografi. Pembelajaran geografi mempelajari tentang fenomena geosfer, dimana perlu dikaji melalui melalui sudut pandang keruangan, kelingkungan dan kompleks wilayah. Hal tersebut sesuai dengan konsep berpikir spasial, yang melibatkan proses berpikir yang kompleks dari berbagai perspektif untuk mempelajari berbagai fenomena. Penelitian ini bertujuan untuk mengetahui pengaruh dan efektivitas penggunaan media webgis inarisk terhadap kemampuan berpikir spasial siswa. Penelitian ini dilakukan menggunakan metode kuantitatif, dengan analisis analisis data melalui Uji-T (Independent Sample T-Test) dan uji efektivitas (Uji N-Gain Score). Hasil nilai Sig (2-tailed) pada analisis Independent Sample T-Test menunjukkan skor 0,001 atau lebih dari 0,05. Rata-rata skor kemampuan berpikir spasial juga menunjukkan pada kelas eksperimen yaitu (XI IPS 2) memiliki nilai 70,3 yang lebih tinggi dibandingkan kelas kontrol (XI IPS 1) yaitu 64,2. Disimpulkan bahwa webgis inarisk sebagai media pembelajaran berpengaruh terhadap kemampuan berpikir spasial siswa. Hasil Uji nilai N-Gain Score juga menunjukkan bahwa media webgis yang digunakan di kelas eksperimen (XI IPS 2) memiliki efektivitas yang lebih baik dalam pencapaian kemampuan berpikir spasial yaitu sebesar 43,7 persen, dibandingkan media peta yang digunakan di kelas kontrol (XI IPS 1) dengan efektivitas 32,09 persen.

This is an open access article under the CC-BY-SA license 
Jurnal Pendidikan Geografi:

Kajian, Teori, dan Praktik dalam Bidang Pendidikan dan Ilmu Geografi

Volume 26, Nomor 2, Juni 2021, Hal 73-84

\section{Corresponding Author:}

Agus Dwi Febrianto

Jurusan Geografi Fakultas Ilmu Sosial

Universitas Negeri Malang

Jl. Semarang No. 5 Malang, Jawa Timur, Indonesia, 65145

E-mail: augustd.febrianto@gmail.com

\section{PENDAHULUAN}

Penggunaan media pembelajaran semakin kompleks seiring dengan semakin berkembangnya teknologi. Hal tersebut berakibat pada semakin bervariasinya jenis-jenis media pembelajaran yang dapat mendukung proses pembelajaran. Menurut Arsyad (2016) media dalam pembelajaran yaitu alat yang digunakan untuk menyampaikan informasi atau mengantarkan pesan-pesan pembelajaran. Setiap mata pelajaran memiliki karakteristik yang berbeda sehingga harus cermat dalam pemilihan media agar pesan pembelajaran dapat tersampaikan dengan baik (Marpanaji et al., 2018). Seperti dalam pembelajaran geografi, salah satu media yang dapat dimanfaatkan untuk mendukung proses pembelajaran adalah media webgis. Penggunaan data spasial sebagai media pembelajaran di sekolah saat ini hanya terbatas pada penggunaan peta tercetak yang kurang interaktif. Melalui webgis, visualisasi data spasial ditampilkan secara lebih nyata sehingga siswa dapat menganalisis fenomena geosfer secara lebih mendalam.

Webgis memiliki berbagai kelebihan untuk digunakan sebagai media pembelajaran. Menurut Baker (2015) dan Saud (2008), media webgis termasuk salah satu teknologi media pembelajaran yang memiliki karakteristik yang interaktif. Karakteristik tersebut memungkinkan siswa untuk mengumpulkan, menganalisis dan melakukan visualisasi data spasial secara lebih baik dibandingkan dengan media lainnya. Penggunaan media berbasis Sistem Informasi Geografis (SIG), memungkinkan pengguna untuk memetakan dan mengajukan pertanyaan mengenai objek atau fenomena secara spasial yang biasanya tidak dapat dilakukan menggunakan peta tercetak (Fargher, 2018).

Jenis informasi dalam webgis dapat berbeda-beda tergantung tujuan atau kebutuhan pembuatan webgis itu sendiri. Seperti media webgis inarisk, media tersebut menampilkan informasi berupa data-data kebencanaan di seluruh wilayah Indonesia. Adapun fitur yang terdapat dalam webgis tersebut yaitu: (1) menyajikan informasi tentang bahaya, kapasitas, kerentanan dan risiko untuk berbagai jenis bencana di wilayah Indonesia, (2) mengunduh peta tematik kebencanaan sesuai dengan cakupan wilayah dan indikator risiko bencana, (3) mengunduh data atribut dan meta data terkait kebencanaan wilayah di Indonesia (BNPB, 2016). Berdasarkan fitur-fitur tersebut maka webgis inarisk secara tidak langsung juga menyajikan mengenai informasi aspek-aspek keruangan geografi seperti persebaran (distribution), pola (pattern), lokasi (location) sesuai dengan fitur-fitur yang ada.

Webgis Inarisk dapat digunakan sebagai media pembelajaran geografi pada materi mitigasi dan adaptasi bencana. Penggunaan webgis inarisk sebagai media pembelajaran mitigasi dan adaptasi bencana memungkinkan siswa untuk membangun kemampuan berpikir spasial siswa terkait risiko bencana di suatu wilayah. Sistem Informasi Geografi (SIG) dalam hal ini yang terhubung dengan website, distribusi tingkat risiko bencana akan dapat diketahui dengan baik, sehingga mampu memberikan gambaran solusi solusi yang lebih akurat bagi para penggunanya (Irawan et al., 2020). Berdasarkan hal tersebut, dengan menggunakan webgis siswa tidak hanya mendapatkan gambaran tentang risiko bencana namun dapat memberikan solusi terkait dengan rencana penanggulangan bencana secara lebih tepat. 
Jurnal Pendidikan Geografi:

Kajian, Teori, dan Praktik dalam Bidang Pendidikan dan Ilmu Geografi

Volume 26, Nomor 2, Juni 2021, Hal 73-84

Kemampuan berpikir spasial penting dalam mempelajari proses mitigasi dan adaptasi bencana yang disajikan dalam materi pembelajaran geografi. Menurut National Research Council (NRC) Committee on Spatial Thinking (2006) menyatakan bahwa berpikir spasial yaitu kemampuan dalam memahami unsur-unsur alam, melakukan representasi informasi dengan berbagai cara atau metode serta melakukan proses penalaran secara keruangan. Hal ini menggambarkan bahwa kemampuan berpikir spasial merupakan kemampuan berpikir dalam mengkaji suatu fenomena melalui berbagai macam perspektif. Sesuai dengan karakteristik pembelajaran geografi, dimana dalam pembelajaran geografi terdapat objek formal geografi yaitu mengkaji fenomena geosfer melalui sudut pandang keruangan, sudut pandang lingkungan dan kompleks wilayah (Wirahayu et al., 2018). Dengan menerapkan proses berpikir spasial, maka diharapkan kajian mengenai proses mitigasi dan adaptasi bencana dapat dilakukan secara lebih kompleks dan mendalam.

Berdasarkan penjabaran diatas, urgensi kemampuan berpikir spasial siswa sangat penting dalam pembelajaran geografi, karena melibatkan proses berpikir yang kompleks berkaitan dengan sudut pandang atau perspektif dalam mengkaji fenomena terkait kebencanaan. Untuk memenuhi hal tersebut maka diperlukan media pembelajaran yang tepat agar mendukung analisis fenomena geosfer secara mendalam sehingga memungkinkan siswa untuk mencapai pemahaman terhadap materi-materi pembelajaran geografi. Penelitian ini difokuskan untuk mengetahui pengaruh penggunaan media webgis inarisk serta efektivitas nya apabila dibandingkan dengan media lainnya yaitu peta standar atau tercetak. Dengan mengetahui pengaruh dan efektivitas dari masingmasing media, maka dapat disimpulkan media manakah yang lebih baik dalam pencapaian kemampuan berpikir spasial siswa sehingga dapat dipertimbangkan untuk digunakan dalam pembelajaran geografi.

\section{METODE}

Penelitian dilakukan menggunakan metode penelitian kuantitatif. Penelitian ini termasuk pada jenis penelitian eksperimen semu (quasi experiment) dengan desain atau rancangan penelitian menggunakan pre-test - post-test control group design. Penelitian eksperimen ini dilakukan untuk mengetahui pengaruh dan efektivitas penggunaan media webgis inarisk terhadap kemampuan berpikir spasial siswa. Subjek yang terlibat yaitu siswa kelas XI IPS di SMAN 2 Malang yang terdiri dari 4 kelas yaitu, XI IPS 1, XI IPS 2, XI IPS 3 dan XI IPS 4. Penentuan sampel yang terdiri dari 2 kelas dipilih berdasarkan nilai ulangan harian (UH) dengan teknik purposive sampling. Didapatkan hasil bahwa kelas XI IPS 1 dan kelas XI IPS 2 dipilih sebagai sampel penelitian karena memiliki rerata ulangan harian (UH) yang hampir setara yaitu 84,03 dan 83,62. Instrumen pengumpulan data adalah berupa soal kemampuan berpikir spasial yang dilakukan uji validitas dan reliabilitas terlebih dahulu sebelum instrumen digunakan untuk proses pengumpulan data. Analisis data dilakukan dengan Uji-T yaitu independent sample t-test setelah dilakukan uji prasyarat yaitu uji normalitas dan uji homogenitas. Sementara untuk mengetahui efektivitas penggunaan media dilakukan uji $\mathrm{N}$-Gain Score dengan membandingkan nilai pre-test dan post-test pada kelas kontrol dan eksperimen.

Pembagian interval kemampuan berpikir spasial dilakukan dengan metode atau aturan Sturges yang membagi skala penilaian kelas interval berdasarkan jumlah data (Scott, 2011). Diperoleh jumlah interval untuk klasifikasi kemampuan berpikir spasial sebanyak 8 interval dengan nilai kemampuan berpikir spasial terendah yaitu 26,5 dan kemampuan berpikir spasial tertinggi yaitu 84. Klasifikasi kemampuan berpikir spasial berdasarkan aturan Sturges disajikan pada Tabel 1. 
Jurnal Pendidikan Geografi:

Kajian, Teori, dan Praktik dalam Bidang Pendidikan dan Ilmu Geografi

Volume 26, Nomor 2, Juni 2021, Hal 73-84

Tabel 1. Klasifikasi Kemampuan Berpikir Spasial Siswa

\begin{tabular}{ccc}
\hline Interval & Skor Interval & Klasifikasi \\
\hline I & $26,5-33,5$ & Tinggi \\
II & $33,6-40,5$ & \\
III & $40,6-47,5$ & \\
IV & $47,6-54,5$ & Sedang \\
V & $54,6-61,5$ & \\
VI & $61,6-68,5$ & Rendah \\
VII & $68,6-75,5$ & \\
VIII & $>75,5$ & \\
\hline
\end{tabular}

HASIL DAN PEMBAHASAN

Penelitian dilakukan di SMA Negeri 2 Malang selama 3 minggu atau dengan kurun waktu tanggal 28 Februari hingga 16 April 2020. Adapun subjek penelitian yaitu siswa kelas XI IIS 1 sebagai kelompok kontrol dan XI IIS 2 sebagai kelompok eksperimen. Data yang terkumpul mencakup nilai pre-test dan post-test di masingmasing kelompok. Dimana pengambilan nilai pre-test dilakukan di awal pertemuan sebelum diberikan perlakuan. Sedangkan pengambilan nilai post-test dilakukan di akhir pertemuan setelah diberikan perlakuan. Adapun dalam proses penelitian ini memiliki keterbatasan yaitu data-data yang ditampilkan dalam webgis inarisk tidak tersedia di seluruh wilayah yang ditampilkan sehingga diperlukan sumber-sumber lain yang relevan agar analisis kebencanaan dapat dilakukan secara mendalam.

\section{Nilai Kemampuan Berpikir Spasial Kelas Kontrol dan Eksperimen}

Kemampuan berpikir spasial dapat dilihat dari nilai kemampuan berpikir sebelum dan setelah setelah diberikannya perlakuan (pre-test dan post-test). Adapun kelas kontrol diberikan perlakuan berupa pembelajaran menggunakan media peta, sedangkan kelas eksperimen diberikan perlakuan berupa pembelajaran menggunakan media webgis inarisk. Berdasarkan distribusi frekuensi nilai pre-test dan post-test baik pada kelas kontrol maupun eksperimen, dapat diketahui terdapat perbedaan distribusi frekuensi apabila ditinjau dari interval nilai kemampuan berpikir spasial akhir. Pada kelas kontrol distribusi frekuensi kemampuan berpikir spasial akhir cenderung merata, yaitu terdapat siswa dengan nilai kemampuan berpikir spasial pada tingkat rendah hingga tinggi. Sedangkan pada kelas eksperimen, setelah dilakukannya perlakuan seluruh siswa memiliki nilai kemampuan berpikir spasial pada tingkat tinggi.

Nilai kemampuan berpikir spasial pada kelas kontrol terdistribusi secara merata dengan rincian 1 siswa memiliki kemampuan berpikir spasial tingkat rendah (interval III), 9 siswa memiliki kemampuan berpikir spasial tingkat sedang (interval IV dan VI), serta 20 siswa memiliki kemampuan berpikir spasial tingkat tinggi (interval VI - VII). Sedangkan pada kelas eksperimen secara keseluruhan atau sebanyak 30 siswa memiliki nilai kemampuan berpikir spasial pada tingkat tinggi. Antara kelas kontrol dan eksperimen keduanya didominasi siswa dengan nilai kemampuan berpikir spasial tinggi setelah diberikannya perlakuan. Namun perbedaan distribusi dan jumlah pada setiap interval nilai kemampuan berpikir spasial memungkinkan bahwa terdapat perbedaan efektivitas pemberian perlakuan yaitu pembelajaran menggunakan media peta dan pembelajaran menggunakan media webgis. Perbandingan kemampuan berpikir spasial siswa antara kelas kontrol dan eksperimen dapat dilihat di Tabel 2 dan 3. 
Jurnal Pendidikan Geografi:

Kajian, Teori, dan Praktik dalam Bidang Pendidikan dan Ilmu Geografi

Volume 26, Nomor 2, Juni 2021, Hal 73-84

Tabel 2. Hasil Tes Kemampuan Berpikir Spasial Kelas Kontrol dan Eksperimen Ditinjau dari Nilai Pre-test

\begin{tabular}{cccc}
\hline \multirow{2}{*}{ Interval } & Skor Interval & \multicolumn{2}{c}{ Frekuensi } \\
\cline { 3 - 4 } & $26,5-33,5$ & Kontrol & Eksperimen \\
\hline I & $33,6-40,5$ & 6 & 3 \\
II & $40,6-47,5$ & 2 & 4 \\
III & $47,6-54,5$ & 6 & 10 \\
IV & $54,6-61,5$ & 10 & 10 \\
V & $61,6-68,5$ & 4 & 1 \\
VI & $68,6-75,5$ & 2 & 1 \\
VII & $>75,5$ & 0 & 1 \\
VIII & & 0 & 0 \\
\hline
\end{tabular}

Tabel 3. Hasil Tes Kemampuan Berpikir Spasial Kelas Kontrol dan Eksperimen Ditinjau dari Nilai Posttest

\begin{tabular}{cccc}
\hline \multirow{2}{*}{ Interval } & Skor Interval & \multicolumn{2}{c}{ Frekuensi } \\
\cline { 3 - 4 } & $26,5-33,5$ & 0 & Kontrol \\
I & $33,6-40,5$ & 0 & 0 \\
II & $40,6-47,5$ & 1 & 0 \\
III & $47,6-54,5$ & 2 & 0 \\
IV & $54,6-61,5$ & 7 & 0 \\
V & $61,6-68,5$ & 13 & 15 \\
VI & $68,6-75,5$ & 5 & 11 \\
VII & $>75,5$ & 2 & 4 \\
VIII & & &
\end{tabular}

\section{Skor Kemampuan Berpikir Spasial Siswa Per Indikator}

Rata-rata skor nilai post-test menunjukkan hampir seluruh sub indikator kemampuan berpikir spasial kelas eksperimen lebih tinggi dibandingkan dengan kelas kontrol. Hanya pada sub indikator mengevaluasi skor rata-rata kelompok kontrol lebih tinggi 0,4 poin daripada kelompok eksperimen. Rata-rata skor pada seluruh sub indikator menunjukkan perbedaan tidak lebih dari 3 poin, dimana poin dengan perbedaan tertinggi terletak pada sub-indikator topografi dengan 2,8 poin. Sementara perbedaan yang paling rendah terletak pada skor sub indikator mengklasifikasi dengan perbedaan 0,1 poin.

Perbedaan rata-rata skor mencerminkan perbedaan pemberian perlakuan pada proses pembelajaran. Kelas kontrol diberikan perlakuan berupa pembelajaran penggunaan media peta, sedangkan pada kelas eksperimen diberikan perlakuan berupa pembelajaran menggunakan media webgis. Masing-masing media tersebut memiliki efektivitas yang berbeda dalam mempengaruhi tingkat kemampuan berpikir spasial pada setiap indikator. Seluruh rata-rata skor di setiap indikator menunjukkan bahwa kelas eksperimen memiliki rata-rata skor yang lebih tinggi apabila dibandingkan kelas kontrol. Pada indikator konsep ruang kelas kontrol memiliki nilai rata-rata sebesar 12,8 sedangkan pada kelas eksperimen memiliki rata-rata sebesar 14,6. Pada indikator alat representasi kelas kontrol memiliki rata-rata skor sebesar 15,8 sedangkan kelas eksperimen memiliki rata-rata sebesar 17,4. Sementara pada indikator proses penalaran kelas eksperimen memiliki rata-rata skor sebesar 12,2 sedangkan pada kelas eksperimen memiliki rata-rata skor 13,1. Data skor kemampuan berpikir spasial siswa per indikator dapat dilihat di Tabel 4. 
Jurnal Pendidikan Geografi:

Kajian, Teori, dan Praktik dalam Bidang Pendidikan dan Ilmu Geografi

Volume 26, Nomor 2, Juni 2021, Hal 73-84

Tabel 4. Data Skor Kemampuan Berpikir Spasial Siswa Per-Indikator

\begin{tabular}{llcc}
\hline \multirow{2}{*}{ Indikator } & \multicolumn{1}{c}{ Sub Indikator } & \multicolumn{2}{c}{ Rata-Rata Skor } \\
\cline { 3 - 4 } Konsep Ruang & Distribusi & 11,6 & Kontrol \\
& Topografi & 13,5 & 13,6 \\
& Asosiasi Spasial & 12,4 & 16,3 \\
\multirow{3}{*}{ Alat Representasi } & 13,8 & 13,3 \\
& Lokasi, Arah, Jarak & 15,8 & 15,4 \\
& Peta dan Tabel & 11,4 & 17,4 \\
& Mengklasifikasi & 12,3 & 11,5 \\
Proses Penalaran & Merencanakan & 13,8 & 13,2 \\
& Mengevaluasi & 10,5 & 13,4 \\
& Mengidentifikasi & 13,4 & 12,1 \\
& Memprediksi & & 14,8 \\
\hline
\end{tabular}

Berdasarkan tabel skor kemampuan berpikir spasial di setiap indikator, dapat disimpulkan bahwa media webgis inarisk membantu identifikasi daerah atau lokasi daerah rawan bencana secara spesifik berkaitan dengan sub-indikator distribusi dan topografi dimana siswa diminta untuk menunjukkan daerah rawan bencana di Jawa Timur. Siswa pada kelas eksperimen mampu menganalisis secara lebih baik yang ditunjukkan dengan perbedaan skor dengan kelas kontrol mencapai 2 poin pada sub indikator distribusi dan 2,8 poin pada sub indikator topografi (Tabel 4). Hal tersebut dikarenakan siswa mendapatkan pengalaman yang lebih baik pada visualisasi data spasial inarisk webgis inarisk dari pada menggunakan peta. Sehingga melalui webgis inarisk siswa mampu mengidentifikasi secara lebih tepat distribusi lokasi daerah rawan bencana berdasarkan karakteristik wilayah seperti kondisi topografi. Menurut Brovelli et al., (2015) menyatakan bahwa webgis memiliki berbagai macam kelebihan diantaranya pengaturan untuk memperbesar dan memperkecil skala. Kelebihan tersebut memungkingkan siswa untuk mengenali lokasi dan pembaruan informasi mengenai daerah rawan banjir dengan lebih cepat dan tepat. Siswa juga mendapatkan gambaran lokasi yang lebih detail apabila skala diatur dalam skala besar, seperti gambaran mengenai kondisi topografi, letak lokasi wilayah berdasarkan kondisi lingkungan pantai, pegunungan atau perkotaan, serta objek-objek terbaru yang rentan terhadap ancaman bencana banjir.

Media webgis inarisk efektif dalam mendukung analisis faktor-faktor yang mempengaruhi daerah rawan dengan tepat. Hal tersebut dibuktikan dengan skor pada sub indikator alat representasi, dimana siswa pada kelas eksperimen memiliki skor yang lebih tinggi dibandingkan kelas kontrol dengan selisih 1,6 poin (Tabel 4). Siswa yang menggunakan media webgis inarisk terbiasa dalam menganalisis kondisi kebencanaan dengan didukung informasi relevan yang disajikan dalam media webgis inarsik tersebut. Kelompok siswa yang menggunakan media webgis inarisk mampu menganalisis kondisi rawan bencana banjir tidak hanya terbatas pada visualisasi data spasial melalui peta namun juga data-data lain yang mendukung hasil analisis faktor-faktor yang mempengaruhi daerah rawan bencana. Menurut Abdalla \& Esmail (2019) dan Ozdilek \& Seker (2004) menyatakan bahwa informasi yang terdapat dalam webgis dapat dipantau secara berkala atau realtime sehingga dalam hal ini membantu dalam proses analisis informasi untuk kebutuhan pemanfaatan data dalam penanggulangan bencana dengan cepat. Berdasarkan hal tersebut dapat diketahui bahwa atribut data atau informasi yang 
Jurnal Pendidikan Geografi:

Kajian, Teori, dan Praktik dalam Bidang Pendidikan dan Ilmu Geografi

Volume 26, Nomor 2, Juni 2021, Hal 73-84

terdapat pada media webgis inarisk selalu mengalami pembaruan sehingga mendukung untuk analisis proses penanggulangan bencana secara berkelanjutan dan tidak hanya bergantung pada visualisasi data spasial. Hal tersebut berbeda apabila dibandingkan dengan media peta dimana analisis kondisi kebencanaan hanya terbatas pada visualisasi data spasial. Melalui webgis mampu memberikan gambaran dan akses informasi yang lebih lengkap, sehingga siswa dapat mengumpulkan, mengolah, menganalisis, menginformasikan, memvisualisasikan dan menginformasikan data spasial kebencanaan secara lebih spesifik dibandingkan dengan penggunaan peta standar (de Lázaro Torres et al., 2017; Edelson et al., 1999).

Media webgis inarisk membantu dalam mengevaluasi serta membuat keputusan secara lebih tepat tentang penanggulangan bencana berkaitan dengan indikator mengevaluasi dan pemahaman terhadap konsep ruang lokasi, distribusi, dan jarak. Hal tersebut sesuai dengan pendapat Kerski \& Baker (2019) dan Kim \& Bednarz (2013), dimana pengalaman dalam penggunaan webgis yang memiliki fitur yang lengkap dan mudah, memungkinkan siswa untuk memahami karakteristik wilayah sekaligus memecahkan masalah berdasarkan informasi yang tersedia. Siswa mampu menentukan berbagai macam keputusan seperti identifikasi lokasi paling berisiko terhadap bencana serta menentukan upaya penanggulangan bencana yang diperlukan yang dibuktikan dengan skor pada sub indikator mengevaluasi mencapai lebih dari 50\% yaitu 13,4 dari skor maksimal 25 (Tabel 4). Menurut BNPB (2016) pada media webgis inarisk tersedia beberapa fitur yang dapat ditampilkan yaitu mengubah tampilan peta dasar (base map) menjadi tampilan yang berbeda-beda seperti peta dasar citra satelit, peta dasar topografi dan peta dasar jaringan jalan. Melalui fitur tersebut siswa mendapatkan perspektif yang berbeda dalam menganalisis secara lebih mendalam tentang kondisi wilayah yang rawan terhadap bencana sehingga dapat menentukan upaya-upaya yang efektif dalam penanggulangan bencana.

Indikator mengevaluasi pada kelas kontrol memiliki skor yang lebih tinggi dibandingkan kelas eksperimen dengan selisih 0,4 poin (Tabel 4). Pada dasarnya skor pada setiap sub indikator tidak mencerminkan kemampuan berpikir spasial secara menyeluruh. Seperti pada sub-indikator mengevaluasi, kelas kontrol memiliki skor yang lebih tinggi dibandingkan kelas eksperimen dikarenakan dalam proses mengevaluasi siswa pada kelas kontrol memiliki sumber atau referensi yang relatif lebih banyak dan tidak hanya terbatas pada media webgis inarisk. Menurut Peng \& Tsou (2003) penggunaan webgis juga memerlukan waktu yang lebih banyak sehingga kurang menguntungkan bagi siswa untuk mengakses sumber-sumber lain dalam waktu yang terbatas. Hal tersebut membuat analisis dan proses evaluasi siswa eksperimen hanya didasarkan pada informasi yang tersedia dalam webgis. Sedangkan bagi siswa kelas kontrol, siswa mampu memberikan gambaran yang lebih beragam sehingga pada sub indikator tersebut siswa pada kelas kontrol memiliki rata-rata skor yang lebih tinggi.

Berdasarkan uraian diatas dapat disimpulkan bahwa terdapat peran atau fungsi penggunaan media webgis inarisk terhadap kemampuan berpikir spasial siswa. Peran tersebut diantaranya; (1) media webgis inarisk efektif dalam membantu identifikasi daerah atau lokasi rawan bencana secara spesifik serta menganalisis penyebab terjadinya bencana banjir berdasarkan karakteristik wilayah secara lebih tepat, (2) Media webgis inarisk efektif dalam mendukung analisis faktor-faktor yang mempengaruhi daerah rawan dengan tepat, dan (3) media webgis inarisk efektif dalam membantu mengevaluasi dan membuat keputusan secara lebih tepat tentang penanggulangan bencana. 
Jurnal Pendidikan Geografi:

Kajian, Teori, dan Praktik dalam Bidang Pendidikan dan Ilmu Geografi

Volume 26, Nomor 2, Juni 2021, Hal 73-84

Tabel 5. Hasil Uji Normalitas Data Kemampuan Berpikir Spasial Kelas Kontrol dan Eksperimen

\begin{tabular}{ccccc}
\hline & \multicolumn{2}{c}{ Kelas Kontrol } & \multicolumn{2}{c}{ Kelas Eksperimen } \\
\cline { 2 - 4 } & Pre-test & Post-test & Pre-test & Post-test \\
\hline Nilai Signifikansi & 0,079 & 0,200 & 0,200 & 0,077 \\
\hline
\end{tabular}

Tabel 6. Hasil Uji Homogenitas Data Kemampuan Berpikir Spasial Kelas Kontrol dan Eksperimen

\begin{tabular}{ccc}
\hline & Levene Statistic & Signifikansi \\
\cline { 2 - 3 } Nilai & 3,129 & 0,082 \\
\hline
\end{tabular}

Tabel 7. Hasil Uji Hipotesis

\begin{tabular}{cccccc}
\hline & \multicolumn{2}{c}{$\begin{array}{c}\text { Levene's Test for Equality of Vari- } \\
\text { ances }\end{array}$} & \multicolumn{2}{c}{ T-Test for Equality of Mean } \\
\cline { 2 - 6 } & $\mathrm{F}$ & Sig. & $\mathrm{t}$ & $\mathrm{df}$ & Sig. (2-tailed) \\
\hline Equal Variances Assumed & 3,329 & 0,073 & 3,335 & 58 & 0,001 \\
\hline
\end{tabular}

Tabel 8. Hasil Uji Efektivitas N Gain Score

\begin{tabular}{lcc}
\hline & $\mathrm{N}$ & Nilai Efektivitas (Mean) \\
\cline { 2 - 3 } Kelas Kontrol & 30 & 32,09 \\
Kelas Eksperimen & 30 & 43,77 \\
\hline
\end{tabular}

\section{Analisis Data Pengaruh Penggunaan Media Webgis Inarisk terhadap Kemampuan Berpikir Spasial}

Uji prasyarat yang terdiri dari uji normalitas dan uji homogenitas dilakukan sebelum uji hipotesis menggunakan uji independent sample t-test. Hasil uji normalitas pada data nilai pre-test dan post-test baik kelas kontrol maupun eksperimen menggunakan Kolmogorov Smirnov menunjukkan nilai signifikansi $>0,05$ dengan rincian 0,079 dan 0,200 pada data pre-test dan post-test kelas kontrol serta 0,200 dan 0,077 pada data pre-test dan post-test kelas eksperimen. Berdasarkan hal tersebut dapat disimpulkan bahwa seluruh data pre-test dan post pada kelas kontrol maupun eksperimen memiliki distribusi yang normal. Hasil uji normalitas data penelitian dapat dilihat pada Tabel 5.

Hasil uji homogenitas menggunakan Levene Statistic menunjukkan bahwa pada keseluruhan data pre-test dan post-test baik pada kelas kontrol maupun eksperimen memiliki nilai signifikansi sebesar 0,082 atau $>0,05$. Maka dapat disimpulkan bahwa data pre-test dan post-test kelas kontrol dan eksperimen bersifat homogen atau memiliki varian yang sama. Hasil uji homogenitas data dapat dilihat pada Tabel 6.

Hasil analisis Uji-T menggunakan independent sample t-test menunjukkan nilai Sig. (2-tailed) adalah 0,001 atau $<0,05$. Selain hal tersebut rata-rata nilai kemampuan berpikir spasial kelas eksperimen lebih tinggi dari kelas kontrol yaitu 70,3 sedangkan kelas kontrol memiliki nilai 64,2. Dapat disimpulkan bahwa $\mathrm{H}_{0}$ ditolak dan $\mathrm{H}_{1}$ diterima yang berarti bahwa media webgis berpengaruh terhadap kemampuan berpikir spasial siswa. Hasil uji hipotesis dapat dilihat pada Tabel 7. 
Jurnal Pendidikan Geografi:

Kajian, Teori, dan Praktik dalam Bidang Pendidikan dan Ilmu Geografi

Volume 26, Nomor 2, Juni 2021, Hal 73-84

\section{Hasil Analisis Uji Efektivitas Penggunaan Media Webgis Inarisk}

Hasil uji efektivitas $N$ gain score menunjukkan pada kelas kontrol memiliki efektivitas sebesar 32,09\%, sedangkan kelas eksperimen memiliki efektivitas sebesar 43,77\%. Menurut Hake (1998) hasil nilai efektivitas keduanya diklasifikasikan pada efektivitas tingkat 'sedang'. Keduanya memiliki selisih $11,68 \%$ yang menunjukkan efektivitas pada kelas eksperimen lebih besar dari kelas kontrol. Berdasarkan hal tersebut dapat disimpulkan bahwa penggunaan media webgis lebih efektif daripada media peta dalam pencapaian kemampuan berpikir spasial siswa yang ditunjukkan dengan nilai gain score pada perbandingan nilai pre-test dan post-test. Hasil uji efektivitas $N$ gain score dapat dilihat pada Tabel 8.

Efektivitas penggunaan media webgis apabila dibandingkan dengan media peta dapat ditinjau dari proses penggunaan media tersebut. Hasil rata-rata nilai post-test menunjukkan bahwa rata-rata nilai post-test pada kelas eksperimen yang menggunakan media webgis maupun kelas kontrol yang menggunakan media peta tidak menunjukkan perbedaan yang cukup signifikan. Hal tersebut didukung dengan skor uji efektivitas dimana baik media webgis inarisk maupun peta sama-sama memiliki skor efektivitas dengan kategori 'sedang', meskipun menurut skor aslinya menunjukkan bahwa media webgis inarisk memiliki efektivitas yang lebih tinggi $(43,77 \%)$ dibandingkan media peta (32,09\%) (Tabel 8). Pada kelas yang menggunakan media webgis maupun peta siswa sulit untuk mengungkapkan visualisasi data spasial secara temporal tentang kondisi rawan bencana di suatu daerah, terutama pada bencana banjir. Namun dalam implementasinya siswa dapat memprediksi pengaruh perubahan kondisi lingkungan terhadap ancaman bencana banjir. Hal tersebut dikarenakan dalam proses implementasi siswa tidak hanya didukung dengan informasi visualisasi data spasial yang ditampilkan pada webgis inarisk maupun peta namun juga data-data lain seperti topografi dan penggunaan lahan yang dapat mendukung hasil analisis siswa. Pemanfaatan sumber belajar dan informasi yang relevan oleh siswa memungkinkan terbentuknya kerangka berpikir critical spatial thinking dan pemahaman yang baik sehingga siswa dapat mengkaji suatu permasalahan secara lebih spesifik dan mendalam (Goodchild \& Janelle, 2010).

Kemampuan berpikir spasial melibatkan kemampuan individu dalam mengidentifikasi atau menganalisis fenomena atau objek. Menurut Kim \& Bednarz (2013) dan Gersmehl \& Gersmehl (2007) menyatakan bahwa kemampuan spasial merupakan kemampuan dalam melakukan visualisasi dan mengaitkan hubungan spasial suatu objek atau fenomena melalui berbagai macam perspektif yang berbeda. Hal tersebut menunjukkan bahwa kemampuan awal dalam diri siswa dapat menentukan hasil akhir dari skor kemampuan berpikir spasial secara menyeluruh. Apabila setiap siswa memiliki perspektif yang berbeda dalam menganalisis kondisi kebencanaan, maka hasil akhir skor kemampuan berpikir spasial ditentukan dari ketepatan konsep yang telah ditetapkan sesuai dengan kisi-kisi dan indikator kemampuan berpikir spasial. National Geographic (2020) menyatakan bahwa pengambilan keputusan merupakan hasil dari proses analisis melalui berbagai macam perspektif dengan cara mengkaji informasi berdasarkan kompleksitas, pengaruh dan keterkaitan dari informasi yang diperoleh.

Pembelajaran materi kebencanaan tidak hanya sebatas siswa dapat mengenali kondisi kebencanaan secara umum maupun secara spesifik pada suatu wilayah. Melalui pembelajaran mitigasi bencana, diharapkan siswa dapat mengenali kondisi rawan bencana di tempat tinggal mereka sehingga mampu meningkatkan kesiapsiagaan dalam menghadapi bencana. Menurut UNISDR (2007) menyatakan bahwa pendidikan kebencanaan yang diimplementasikan di lembaga sekolah dapat membangun 
Jurnal Pendidikan Geografi:

Kajian, Teori, dan Praktik dalam Bidang Pendidikan dan Ilmu Geografi

Volume 26, Nomor 2, Juni 2021, Hal 73-84

kesiapsiagaan siswa yang lebih baik dalam menghadapi bencana. Media webgis inarisk sendiri berperan dalam menyediakan informasi kebencanaan yang aktual sesuai dengan kondisi wilayah, dimana hal tersebut diperlukan untuk meningkatkan pengetahuan siswa tentang kondisi lingkungannya serta dapat menerapkannya di kehidupan sehari-hari (Irawan et al., 2020). Peran sekolah dalam membangun kesiapsiagaan siswa dapat dilakukan dengan memaksimalkan segala sumberdaya seperti implementasi penggunaan teknologi spasial kebencanaan seperti webgis inarisk dalam pembelajaran. Penggunaan media webgis yang memberikan informasi kebencanaan seperti webgis inarisk dapat membantu siswa mengenali kondisi rawan bencana di sekitar sekaligus meningkatkan kemampuan berpikir spasial dalam kebencanaan seperti mengetahui mitigasi dan kesiapsiagaan dalam menghadapi bencana (Abdalla \& Esmail, 2019).

\section{KESIMPULAN}

Penggunaan media webgis inarisk berpengaruh terhadap kemampuan berpikir spasial siswa kelas XI SMAN 2 Malang pada materi mitigasi dan adaptasi bencana dengan hasil analisis independent sample t-test menunjukkan nilai Sig. (2-tailed) adalah 0,001 atau $<0,05$. Selain hal tersebut rata-rata nilai kemampuan berpikir spasial kelas eksperimen lebih tinggi dari kelas kontrol yaitu 70,3 sedangkan kelas kontrol memiliki nilai 64,2. Efektivitas media webgis inarisk pada pencapaian kemampuan berpikir spasial siswa dilakukan perbandingan dengan media peta. Didapatkan hasil bahwa media webgis inarisk lebih efektif daripada media peta dalam mendukung pencapaian terhadap kemampuan berpikir spasial dengan nilai efektivitas masing-masing sebesar $43,77 \%$ dan $32,09 \%$. Media webgis inarisk menyajikan data atau informasi yang akurat serta fiturfitur yang lengkap sehingga memudahkan siswa untuk analisis kebencanaan secara lebih mendalam. Hal tersebut didukung dengan rata-rata nilai akhir kemampuan berpikir spasial dimana siswa pada kelas yang menggunakan media webgis inarisk memiliki skor yang lebih tinggi dibandingkan siswa yang menggunakan media peta.

\section{DAFTAR RUJUKAN}

Abdalla, R., \& Esmail, M. (2019). WebGIS decision support system for disaster management. In Advances in Science, Technology and Innovation (pp. 91-96). Springer Nature. https://doi.org/10.1007/978-3-030-03828-1 10

Arsyad, A. (2016). Media Pembelajaran. Rajawali Press.

Baker, T. R. (2015). WebGIS in education. In Geospatial technologies and Geography education in a changing world: Geospatial practices and lessons learned (pp. 105115). Springer Japan. https://doi.org/10.1007/978-4-431-55519-3 9

BNPB. (2016). \#SEMUA ADA DI INARISK.

Brovelli, M. A., Zamboni, G., \& Arias Muñoz, C. (2015). From paper maps to the digital earth and the internet of places. Rendiconti Lincei, 26(1), 97-103. https:// doi.org/10.1007/s12210-015-0437-y

de Lázaro Torres, M. L., De Miguel González, R., \& Morales Yago, F. J. (2017). WebGIS and Geospatial technologies for landscape education on personalized learning contexts. ISPRS International Journal of Geo-Information, 6(11), 350. https://doi.org/10.20944/preprints201708.0089.v1

Edelson, D. C., Gordin, D. N., \& Pea, R. D. (1999). Addressing the challenges of inquiry -based learning through technology and curriculum design. Journal of the Learning Sciences, 8(3-4), 391-450. https://doi.org/10.1080/10508406.1999.9672075

Fargher, M. (2018). WebGIS for Geography education: Towards a GeoCapabilities approach. ISPRS International Journal of Geo-Information, 7(3), 111. https:// 
Jurnal Pendidikan Geografi:

Kajian, Teori, dan Praktik dalam Bidang Pendidikan dan Ilmu Geografi

Volume 26, Nomor 2, Juni 2021, Hal 73-84

doi.org/10.3390/ijgi7030111

Gersmehl, P. J., \& Gersmehl, C. A. (2007). Spatial thinking by young children: Neurologic evidence for early development and "educability." Journal of Geography, 106(5), 181-191. https://doi.org/10.1080/00221340701809108

Goodchild, M. F., \& Janelle, D. G. (2010). Toward critical spatial thinking in the social sciences and humanities. In GeoJournal (Vol. 75, Issue 1, pp. 3-13). Springer. https://doi.org/10.1007/s10708-010-9340-3

Hake, R. R. (1998). Interactive-engagement versus traditional methods: A six-thousandstudent survey of mechanics test data for introductory physics courses. American Journal of Physics, 66(1), 64-74. https://doi.org/10.1119/1.18809

Irawan, L. Y., Nabila, N., Panoto, D., Darmansyah, A. C., Rasyidah, A. N., Boro, C. A., \& Suryo, T. A. (2020). Penilaian risiko bencana di Sub DAS Amprong menggunakan pendekatan GIS. JPIG (Jurnal Pendidikan Dan Ilmu Geografi), 5(2), 107-121. https://doi.org/10.21067/jpig.v5i2.4677

Kerski, J. J., \& Baker, T. R. (2019). Infusing educational practice with Web GIS. In Geospatial Technologies in Geography Education (pp. 3-19). Springer, Cham. https://doi.org/10.1007/978-3-030-17783-6_1

Kim, M., \& Bednarz, R. (2013). Development of critical spatial thinking through GIS learning. Journal of Geography in Higher Education, 37(3), 350-366. https:// doi.org/10.1080/03098265.2013.769091

Marpanaji, E., Mahali, M. I., \& Putra, R. A. S. (2018). Survey on how to select and develop learning media conducted by teacher professional education participants. Journal of Physics: Conference Series, 1140(1), 12014. https://doi.org/10.1088/1742$6596 / 1140 / 1 / 012014$

National Geographic. (2020). Looking at the world in multiple ways in national Geographic society. National Geographic. https://www.nationalgeographic.org/ education/about/national-geography-standards/geographic-perspectives/

National Research Council (NRC) Committee on Spatial Thinking. (2006). Learning to think spatially. NRC Publication. https://books.google.co.id/books? $\mathrm{hl}=$ en\&lr=\&id=1GKbAgAAQBAJ\&oi=fnd\&pg=PT19\&dq=Learning + to + think + spati ally\&ots=sqMfQUwvR V\&sig=-2o-

6rYhxwhgyNLUjYNKmUPKai0\&redir_esc $=\mathrm{y} \# \mathrm{v}=$ onepage $\& \mathrm{q}=$ Learning to think spatially\& $\mathrm{f}=$ false

Ozdilek, O., \& Seker, D. Z. (2004). A web-based application for real-time GIS. XXth ISPRS Congress, 1-5.

Peng, Z. R., \& Tsou, M. H. (2003). Internet GIS: distributed geographic information services for the internet and wireless networks. John Wiley \& Sons Publication. https://books.google.co.id/books?hl=en\&lr=\&id=sk5UHK-

FJM8C\&oi=fnd\&pg=PR25\&dq=Internet+GIS:+Distributed+Geographic+Information+Services+for+the+Internet+and+wireless+net-

+works\&ots=FyOvftIQea\&sig $=$ AtIkMBD0Ej6gLxH_Jifk4j3iyFI\&redir_esc $=y \# v=$ on epage \&q=Interne

Saud, U. (2008). Inovasi Pendidikan. Penerbit Alfabeta.

Scott, D. W. (2011). Sturges' and Scott's rules. In International Encyclopedia of Statistical Science (pp. 1563-1566). Springer Berlin Heidelberg. https:// doi.org/10.1007/978-3-642-04898-2_578

UNISDR. (2007). International Strategy for Disaster Reduction (ISDR). UNISDR. https:/www.unisdr.org/2007/campaign/wdrc-2006-2007.htm

Wirahayu, Y. A., Purwito, H., \& Juarti, J. (2018). Penerapan model pembelajaran 
Jurnal Pendidikan Geografi:

Kajian, Teori, dan Praktik dalam Bidang Pendidikan dan Ilmu Geografi

Volume 26, Nomor 2, Juni 2021, Hal 73-84

Treffinger dan ketrampilan berpikir divergen mahasiswa. Jurnal Pendidikan Geografi: Kajian, Teori, Dan Praktek Dalam Bidang Pendidikan Dan Ilmu Geografi, 23(1), 30-40. https://doi.org/10.17977/um17v23i12018p030 